\title{
The Face of Collegiate Aviation: Factors Impacting Self-Selection of Collegiate Aviation Programs
}

\author{
Julie Massie Clark \\ Delta State University
}

\begin{abstract}
The purpose of this study was to determine the factors that influence student selection of a four-year post-secondary commercial aviation program. Additionally, this study attempted to determine if there is a difference in factors based upon gender and race that influenced choice of a four-year post-secondary commercial aviation program. Specifically, the primary focus was to collect data from aviation students regarding choice factors in enrolling in four-year post-secondary institutions. The survey method allowed the researcher to collect data from students enrolled in four-post secondary aviation programs to determine the current factors influencing student choices. In addition, the study examined enrollment data by gender and race of students in 23 four-year post-secondary aviation programs.

Findings suggest the factors that influence selection of a four-year post-secondary aviation program are similar for all aviation students. The students that are drawn to four-year post-secondary aviation programs are there simply for aviation. Specifically, study results suggest that students enroll in fouryear post-secondary aviation programs because they want to fly (62\%). Additionally, the 10 most influential program and institutional characteristics that attract students to collegiate aviation were program educational quality, university reputation, condition of equipment, institutional educational quality, location of institution, small class size, safety concerns, program characteristics, student to faculty ratio, and distance from home. These findings will be especially helpful to collegiate aviation programs that actively recruit students to their institution.
\end{abstract}

\section{INTRODUCTION}

Recruiting and student selection is important to post-secondary institutions because there is a relationship between the number of students, course offerings, and tuition costs (Astin, 1975). Institutions use many methods to attract students to their respective colleges including written materials, campus presentations and electronic media (Hossler, 1999; Stonewater, 1999). Hurd (2000) stated that institutions that successfully attract learners to their campuses treat students as customers.

Prospective college students must make three decisions according to Astin (1977): a) whether to attend college, b) where to go, and c) how to go (p.1). These students must consider many factors when choosing an institution of higher learning (Astin, 1975; Manski \& Wise, 1983; Tinto, 1987). The student's academic performance in high school, cost of tuition and level of parental education were factors in the institutional selection by students (Astin; Manski \& Wise).

Luedtke (1993), in a study that sought to maximize participation in collegiate aviation, reported that with colleges and universities facing lower enrollment numbers due to the slow economy, institutions must seek to attract all students (Luedtke, 1993). While females enter postsecondary institutions at a greater rate than their male counterparts (Tinto, 1987), female students do not choose commercial aviation programs to the same degree (Luedtke, 1993; Moore, 1999). Similarly, minority students do not choose to enter commercial aviation programs at the same rate as Caucasian male students (Luedtke; Moore). For example, in the Fall 2002 semester, female enrollment at postsecondary aviation programs averaged 14 percent with minority enrollment less than 10 percent (Clark, 2002 \& 2004). In contrast, women enrolled in post-secondary institutions in the Fall 1999 semester at a rate of 53.6 percent with minority enrollment of 30.6 percent (IPEDS, 2000).

\section{BACKGROUND}

The aviation industry has changed over the years; however the demographics of those who have chosen to enter the field have remained relatively unchanged in the last thirteen years 
(Luedtke, 1993). The demand for and growth of air travel had risen steadily from the 1960s until the tragedy on September 11, 2001 (FAA, 2001). Prior to September 11, 2001, air travel was expected to continue growing even though $60 \%$ of the pilots flying domestic flights were expected to retire by 2015 (Mangan, 2000). While the aviation industry has continued to recover, women and minorities are still underrepresented in the field (Bowen, FAA, U.S. Department of Education, 1992; WIAI, 2001; Luedtke). For example in 2001 Female pilots made up less than three percent of the total pilots flying for airlines (WIAI). Similarly, minorities represent less than five percent with three percent of Hispanic origin and less than two percent black (U.S. Department of Education). Congress acknowledged that there are few women and minorities in the field; and was "interested in ways to increase the access of women and minorities to civilian aviation jobs" (U.S. Department of Education, 1992, p.1).

One of the implications of military downsizing has been that collegiate aviation has become a major source of training for pilots flying for commercial airlines (Karp, McCurry, Turney \& Harms, 1999; U.S. Department of Education, 1992). Mangan (2001) reported that "six years ago, $80 \%$ of the nation's newly hired pilots had been trained by the armed forces; now just $50 \%$ of the new hires have military flying experience" (p.1). It was projected that by 2002, that only $10 \%$ of the newly hired pilots would be trained by the military (Mangan). Similarly, the National Academy of Sciences Committee recommended that aviation companies and institutions with aviation programs combine their efforts to seek and attract larger minority and female enrollment to aviation programs (U.S. Department of Education, 1992).

The end goal of post-secondary aviation programs is to provide trained aviators for the commercial aviation field (U.S. Department of Education, 1992). Additionally, recruiting to college programs can impact actual commercial aviation employee statistics (U.S. Department of Education). If four-year aviation programs can increase female and minority enrollment, an increase in females and minorities in commercial aviation should also occur (Brazziell \& Brazziell, 1997; Hurd, 2000; Lipton, 2000;
Moore, 1999; U.S. Department of Education). Therefore, it is important to determine why female and minority students choose to enroll in collegiate aviation programs (Luedtke, 1993).

The purpose of this study was to determine the factors that influence student selection of a four-year post-secondary commercial aviation program. Additionally, this study attempted to determine if there is a difference in factors based upon gender and race that affected students' decisions to enroll in specific four-year postsecondary commercial aviation programs.

\section{Research Questions}

1. What factors influence students to enroll in collegiate aviation programs?

2. What institutional characteristics attract students to collegiate aviation programs?

3. Is there a difference in factors and institutional characteristics that attract male versus female students to collegiate aviation programs?

4. Is there a difference in factors and institutional characteristics that attract minority students versus non-minority students to collegiate aviation programs?

\section{SIGNIFICANCE OF THE STUDY}

Four-year collegiate aviation programs traditionally have low numbers of female and minority students. This study focused on student selection factors of collegiate aviation programs and analyzed those factors that were assumed to attract commercial aviation students. If the identified factors are proven to improve student selection and enrollment in institutions of higher learning with aviation programs, these factors may be implemented by institutions and programs in order to increase the number of female and minority students. Additionally, the outcome of this study may be used by institutions that are interested in developing four-year aviation programs that successfully attract a wide variety of students. For recruiting and retention efforts, it is important to determine why female and minority students do not enroll in collegiate aviation programs at the same rate of white males, and consequently, are not well represented in the field of aviation.

The survey instrument allowed the researcher to collect data from participants to 
discover influencing factors in order to generalize them to the collegiate aviation population (Gall, Borg, \& Gall, 1996). Specifically, the primary focus was to collect data from aviation students regarding choice factors in enrolling in four-year post-secondary institutions. The survey method allowed the researcher to collect data from students enrolled in four-post secondary aviation programs to determine the current factors influencing student selection. In addition, the study examined enrollment data by gender and race of students in 23 four-year post-secondary aviation programs.

\section{SAMPLE}

The sample for this study included students with declared commercial aviation majors enrolled in freshman aviation courses. In addition, all students in the sample attended a four-year post-secondary aviation program with paid membership in the National Intercollegiate Flight Association (NIFA). The National Intercollegiate Flight Association is an association of universities and colleges, both two-year and four-year institutions that develop, advance, promote, encourage and foster safety in aviation. To be eligible for membership, each school must be an accredited institution of higher learning with a regional educational accrediting association. The National Intercollegiate Flight Association had a membership of 60 post- secondary institutions at the time of this study.

Two-year institutions were eliminated from the study because a four-year degree is typically required to work for the commercial airlines. Additionally, students enrolled in two-year aviation programs usually transfer to a four-year institution to compete degree requirements in order to pursue careers in aviation. Thirty-eight four-year post-secondary aviation programs with paid membership in NIFA were identified in the United States at the time of this study. Two schools were eliminated because they no longer functioned as four-year post-secondary aviation programs. A third school was eliminated because its participation required monetary compensation to release enrollment data and administer the survey. Thirty schools agreed to participate in the study. Upon review of the respective institutional review boards two schools withdrew their commitment to participate because the researcher was not on faculty at their institutions. The target population included all commercial aviation majors enrolled in post-secondary commercial aviation programs in the United States.

\section{INSTRUMENT}

The instrument was developed in Fall 2003, from a literature review of factors that influenced student selection of four-year postsecondary institutions. Specifically, the factors found in the literature reviews were used to adapt the Ancrum-Smalls, Hagan, Kalbach, Smith-Wagner \& Shepard (2000) survey instrument for use in four-year post-secondary institutions with commercial aviation programs. The survey instrument was divided into several sections to determine demographics, financial factors, program characteristics, and institutional characteristics of student selection.

All results are reported as aggregate data with the intention of not identifying a particular four-year post-secondary aviation program. Twenty-three of the 28 programs (82\%) that agreed to participate in the study returned completed surveys (see Table 1).

Table 1. Summary of Population, Sample, and Four-Year Post-Secondary Aviation Programs Returning Surveys

\begin{tabular}{|l|l|l|}
\hline & N & P \\
\hline Population (NIFA, 4yr) & 38 & $100 \%$ \\
\hline Sample & 28 & $74 \%$ \\
\hline Returned Surveys & 23 & $\mathbf{8 2 . 1 \%}$ \\
\hline
\end{tabular}

The number of surveys mailed to each participating institutions was decided by the departmental chairperson from their respective institutions. Collectively, the chairpersons requested 983 surveys for the 23 four-year postsecondary institutions participating in the study. Seven hundred fifty-one surveys were returned for an overall subject return rate of $76 \%$ (see Table 2) 
Table 2. Summary of Subject Sample

\begin{tabular}{|l|l|l|}
\hline & $\mathrm{N}$ & $\mathrm{P}$ \\
\hline Number of mailed surveys & $\mathbf{9 8 3}$ & $\mathbf{1 0 0 \%}$ \\
\hline $\begin{array}{l}\text { Number of returned } \\
\text { surveys }\end{array}$ & 751 & $\mathbf{7 6 . 4 \%}$ \\
\hline
\end{tabular}

Summary data of gender, age, and racial category confirmed the literature review results with a high percentage of Caucasian males in four-year post-secondary aviation programs (see
Table 3). Specifically, the modal respondent was male (85.5\%), age 17-20 (65.2\%), and Caucasian (79.9\%). Female students represented thirteen percent of the respondents. Collectively, the minority racial category was sixteen percent. Specifically, African Americans or Blacks (5.6\%), Asian or Pacific Islanders (4.3\%), American Indian, Alaskan Native (1.5\%), and Hispanic (4.7\%) were included in the minority category.

Table 3. Summary of Subjects Gender, Age, and Racial Category

\begin{tabular}{|c|c|c|c|}
\hline Variable & & $\mathrm{n}$ & $\mathrm{P}$ \\
\hline \multicolumn{4}{|l|}{ Gender } \\
\hline & Female & 98 & $13 \%$ \\
\hline & Male & 642 & $85.5 \%$ \\
\hline & Total Reported & 740 & $98.5 \%$ \\
\hline & Missing & 11 & $1.5 \%$ \\
\hline & Grand Total & 751 & $100 \%$ \\
\hline \multicolumn{4}{|l|}{ Age } \\
\hline & $17-20$ & 490 & $65.2 \%$ \\
\hline & $21-25$ & 187 & $24.9 \%$ \\
\hline & $26-29$ & 41 & $5.5 \%$ \\
\hline & $30-35$ & 13 & $1.7 \%$ \\
\hline & $36-40$ & 5 & $.7 \%$ \\
\hline & Over 40 & 7 & $.9 \%$ \\
\hline & Total Reported & 743 & $98.9 \%$ \\
\hline & Missing & 8 & $1.1 \%$ \\
\hline & Grand Total & 751 & $100 \%$ \\
\hline \multicolumn{4}{|c|}{ Racial Category } \\
\hline & African American or Black & 42 & $5.6 \%$ \\
\hline & Asian or Pacific Islander & 32 & $4.3 \%$ \\
\hline & American Indian, Alaskan Native & 11 & $1.5 \%$ \\
\hline & Caucasian & 600 & $79.9 \%$ \\
\hline & Hispanic & 35 & $4.7 \%$ \\
\hline & Other & 11 & $1.5 \%$ \\
\hline & Total Reported & 731 & $97.3 \%$ \\
\hline & Missing & 20 & $2.7 \%$ \\
\hline & Grand Total & 751 & $100 \%$ \\
\hline
\end{tabular}




\section{RESULTS}

Research Question 1 Research question 1 asked what factors influence students to enroll in collegiate aviation programs. The factors that influenced students to select four-year postsecondary commercial aviation programs are listed in rank order of very influential to not influential (see Table 5); this list included a variety of personal motivating factors, program factors, and institutional factors. The 10 most frequently selected as very influential, in descending order were, (1) always wanted to be a pilot (62\%), (2) program educational quality (49\%), (3) potential money in the field (37\%), (4) university reputation (38\%), (5) condition of equipment (34\%), (6) institutional educational quality (32\%), (7) availability of financial aid (31\%), (8) availability of scholarships (30\%), (9) interactions and perceptions of aviation community (30\%), and (10) location of the institution (30\%).

Research Question 2 Research question 2 asked what program and institutional characteristics attract students to collegiate aviation programs. The factors that influenced students to select four-year post-secondary commercial aviation programs are listed in rank order of very influential to not influential (see Table 5); The 10 most influential program and institutional characteristics that attract students to collegiate aviation in descending order were, (2) program educational quality (49\%), (4) university reputation (38\%), (5) condition of equipment (34\%), (6) institutional educational equality (32\%), (10) location of institution (30\%), (12) small class size (26\%), (13) safety concerns (26\%), (14) program characteristics (24\%), (15) student to faculty ratio (24\%), and (16) distance from home (22\%).

Research Question 3 Research question 3 asked if there is a difference in factors that attract male verses female students to enroll in four-year post-secondary aviation programs. There is little difference in factors that attract male verses female students to enroll in collegiate aviation programs (see Table 6). More than half (62\%) of all participants rated the top survey item that influenced them to select a four-year postsecondary commercial aviation program, as very influential, and recorded "that they always wanted to fly" males (65\%) and females (58\%). Additionally, both male (50\%) and female (49\%) participants rated program educational quality as very influential. University reputation was ranked second behind program educational quality with male students (40\%) and female students (36\%). Institutional quality was very influential to a few more female students (40\%) when compared to their male counterpart (32\%).

Fifty chi-square analyses were computed for gender and the fifty factors using SPSS 11.0 (SPSS, 1999 \& 2002). With 4 degrees of freedom and an alpha level of .05, and critical value of 9.49, two of the fifty survey items reported a gender difference. Female students reported that "the presence of Women in Aviation International (WIA)" and the "OnCampus Visit" significantly influenced their selection of a four-year post-secondary aviation program. The value of $\mathrm{x}=57.311 \mathrm{p}>.05$ for WIA and $x=14.488 p>.05$ for campus visit. The factors that influenced students to select fouryear post-secondary commercial aviation programs are listed in rank order of very influential to not influential (see Table 5). In rank order of importance the on-campus visit was 24 out of 50. Similarly WIA was ranked 44 out of 50 .

Research Question 4 Research question 4 asked if there is a difference in factors and institutional characteristics that attract minority students verses non-minority students to collegiate aviation programs. Each participant was asked to circle the racial composition that described them. The categories included AfricanAmerican or black (6\%), Asian or Pacific Islander (4\%), American Indian or Alaskan Native (2\%), Caucasian (80\%), and Hispanic (5\%).

Similarly there is diminutive difference in factors that attract minority and majority race students to enroll in four-year post secondary aviation programs (see Table 7). Collectively African-Americans or blacks, Asian or Pacific Islanders American Indians or Alaskan Natives and Hispanic (57\%) rated the top survey items that influenced them to select four-year postsecondary commercial aviation program as very influential, and recorded that "they always 
wanted to fly" similarly to the Caucasian (66\%) participants. Program quality was the second most frequently selected by both AfricanAmericans or blacks, Asian or Pacific Islanders American Indians or Alaskan Natives and Hispanic (52\%) and Caucasian (50\%) participants. University reputation was very influential for African-Americans or blacks, Asian or Pacific Islanders American Indians or Alaskan Natives and Hispanic (43\%) and Caucasian (39\%) when selecting a four-year post-secondary aviation programs. Institutional quality was nearly the same as university reputation for both minority (43\%) and majority (32\%) in influencing selection of a collegiate aviation program.

Fifty chi-square analyses were computed for racial category and the fifty factors using SPSS 11.0 (SPSS, 1999 \& 2002). With 20 degrees of freedom and an alpha level of .05, and critical value of 31.41 , seven of the 50 survey items reported a difference based upon racial composition. Specifically, AfricanAmericans or blacks, Asian or Pacific Islanders
American Indians or Alaskan Natives and Hispanic were statistically different with the value of $x=37.62 p^{>} .05$ for presence of WIA, the value of $\mathrm{x}=35.62 \mathrm{p}>.05$ for institutional admission, value of $\mathrm{x}=50.931 \mathrm{p}>.05$ for handicap/disability support , value of $x=45.085$ $p>.05$ for gender of faculty, value of $x=57.822$ p>.05 for race of faculty, value of $x=33.835$ $\mathrm{p}>.05$ for student gender, and the value of $\mathrm{x}=$ $38.344 \mathrm{p}>.05$ for student race when compared to their Caucasian counterpart. The factors that influenced students to select four-year postsecondary commercial aviation programs are listed in rank order of very influential to not influential (see Table 5). The rank order of the significantly higher factors for AfricanAmericans or blacks, Asian or Pacific Islanders American Indians or Alaskan Natives and Hispanics varied and was (a) presence of WIA (44), (b) institutional admission criteria (29), (c) handicap/disability support (50), (d) gender of faculty (45), (e) race of faculty (49), (f) student gender (47), and (g) student race (46).

Table 5. Summary of Percentages for Factors Influencing Choice of Four-Year Post-Secondary Commercial Aviation Program in Rank Order of Very Influential $(n=751)$

\begin{tabular}{|l|l|l|l|l|l|}
\hline Survey Item & $\begin{array}{c}\text { Very } \\
\text { Influential } \\
(\%)\end{array}$ & $\begin{array}{c}\text { Influential } \\
\mathbf{( \% )}\end{array}$ & $\begin{array}{c}\text { Somewhat } \\
\text { Influential } \\
(\mathbf{\%})\end{array}$ & $\begin{array}{c}\text { Minimally } \\
\text { Influential } \\
(\%)\end{array}$ & $\begin{array}{c}\text { Not } \\
\text { Influential } \\
(\%)\end{array}$ \\
\hline Always wanted to be a pilot & 62.6 & 16.5 & 10.4 & 2.0 & 5.0 \\
\hline Program Educational Quality & 49.0 & 31.7 & 31.7 & 2.1 & 2.9 \\
\hline Potential Money in the Field & 37.3 & 33.4 & 14.8 & 5.6 & 6.1 \\
\hline University Reputation & 38.1 & 35.6 & 14.5 & 5.6 & 3.7 \\
\hline Condition of Equipment & 33.6 & 37.8 & 17.6 & 5.2 & 4.1 \\
\hline $\begin{array}{l}\text { Institutional Educational } \\
\text { Quality }\end{array}$ & 32.1 & 37.0 & 19.3 & 4.9 & 3.6 \\
\hline Availability of Financial Aid & 30.6 & 25.8 & 18.4 & 8.1 & 14.4 \\
\hline Availability of Scholarships & 30.0 & 23.0 & 20.4 & 10.3 & 13.2 \\
\hline $\begin{array}{l}\text { Interactions/Perceptions of } \\
\text { Aviation Community }\end{array}$ & 30.0 & 36.9 & 20.9 & 6.0 & 4.5 \\
\hline Location of Institution & 29.6 & 28.2 & 20.5 & 9.3 & 8.9 \\
\hline
\end{tabular}




\begin{tabular}{|c|c|c|c|c|c|}
\hline \multicolumn{6}{|l|}{ Table 5 (continued). } \\
\hline Survey Item & $\begin{array}{c}\text { Very } \\
\text { Influential } \\
(\%)\end{array}$ & $\begin{array}{c}\text { Influential } \\
(\%)\end{array}$ & \begin{tabular}{|c|} 
Somewhat \\
Influential \\
$(\%)$
\end{tabular} & $\begin{array}{c}\text { Minimally } \\
\text { Influential } \\
(\%)\end{array}$ & \begin{tabular}{|c} 
Not \\
Influential \\
$(\%)$
\end{tabular} \\
\hline Tuition and Fees & 26.9 & 28.1 & 19.3 & 9.3 & 13.8 \\
\hline Small Class Size & 26.2 & 30.9 & 25.6 & 8.5 & 7.1 \\
\hline Safety Concerns & 25.7 & 34.1 & 22.4 & 8.5 & 7.7 \\
\hline Program Characteristics & 24.4 & 39.9 & 20.9 & 6.3 & 6.3 \\
\hline Student/Faculty Ratio & 23.6 & 29.3 & 27 & 10.7 & 8.1 \\
\hline Distance from Home & 22.0 & 24.4 & 19.8 & 12.5 & 18.5 \\
\hline $\begin{array}{l}\text { Availability to Work while } \\
\text { Attending Classes }\end{array}$ & 21.7 & 23.0 & 21.6 & 13.0 & 18.0 \\
\hline Faculty Commitment & 21.2 & 28.9 & 24.9 & 9.5 & 12.6 \\
\hline $\begin{array}{l}\text { Number of Years Program has } \\
\text { existed }\end{array}$ & 19.3 & 27.2 & 26.2 & 13.4 & 10.9 \\
\hline Faculty Reputation & 19.2 & 34.8 & 25.7 & 9.1 & 8.7 \\
\hline Availability of Internships & 19.2 & 26.9 & 26.1 & 14.2 & 11.7 \\
\hline Campus Appearance & 19.0 & 29.8 & 26.9 & 11.2 & 10.4 \\
\hline Program Philosophy & 18.6 & 38.9 & 24.4 & 8.5 & 7.9 \\
\hline On-Campus Visit & 18.1 & 26.8 & 23.6 & 11.9 & 16.6 \\
\hline $\begin{array}{l}\text { Interactions/Perceptions of } \\
\text { Faculty }\end{array}$ & 17.6 & 34.4 & 25.6 & 9.9 & 9.3 \\
\hline Availability of Classes & 16.8 & 35.4 & 28.0 & 11.7 & 6.7 \\
\hline Influence of a Family Member & 16.4 & 20.1 & 20.0 & 16.2 & 24.0 \\
\hline Course Requirements & 15.3 & 38.2 & 29.8 & 8.8 & 6.0 \\
\hline Admission Criteria & 14.6 & 37.5 & 28.2 & 9.2 & 8.0 \\
\hline $\begin{array}{l}\text { Length of Program (course } \\
\text { work) }\end{array}$ & 14.1 & 35.8 & 33.7 & 9.6 & 5.3 \\
\hline Familiarity of Campus & 13.8 & 23.2 & 27.6 & 15.8 & 16.4 \\
\hline $\begin{array}{l}\text { Campus Support Facilities } \\
\text { (computer lab, library, etc.) }\end{array}$ & 13.7 & 24.4 & 26.8 & 15.6 & 17.3 \\
\hline Core Requirements & 13.4 & 41.3 & 30.0 & 7.7 & 5.5 \\
\hline Presence of Flight Team & 13.3 & 18.5 & 24.5 & 18.8 & 23.6 \\
\hline Influence of a Friend & 13.3 & 15.4 & 22.1 & 18.4 & 27.6 \\
\hline $\begin{array}{l}\text { Interactions/Perceptions of } \\
\text { Alumni }\end{array}$ & 12.6 & 25.6 & 26.2 & 17.7 & 15.7 \\
\hline Interaction of Current Students & 12.1 & 24.6 & 28.2 & 13.7 & 18.1 \\
\hline Faculty Mentorship & 9.2 & 21.8 & 29.0 & 19.4 & 17.7 \\
\hline
\end{tabular}




\begin{tabular}{|l|l|l|l|l|l|}
\hline Table 5 (continued). & \multicolumn{1}{|c|}{$\begin{array}{l}\text { Very } \\
\text { Influential } \\
\mathbf{( \% )}\end{array}$} & $\begin{array}{c}\text { Influential } \\
\mathbf{( \% )}\end{array}$ & $\begin{array}{c}\text { Somewhat } \\
\text { Influential } \\
\mathbf{( \% )}\end{array}$ & $\begin{array}{c}\text { Minimally } \\
\text { Influential } \\
\mathbf{( \% )}\end{array}$ & $\begin{array}{c}\text { Not } \\
\text { Influential } \\
\mathbf{( \% )}\end{array}$ \\
\hline Brochures/Pamphlets & 9.2 & 21.3 & 28.8 & 20.2 & 17.2 \\
\hline Student Body Diversity & 8.9 & 18.6 & 24.5 & 23.7 & 21.3 \\
\hline Faculty Research & 8.0 & 20.1 & 28.4 & 19.3 & 21.3 \\
\hline Parking Availability & 7.6 & 10.5 & 19.7 & 20.6 & 38.3 \\
\hline $\begin{array}{l}\text { Presence of Similar Age } \\
\text { Students }\end{array}$ & 7.2 & 18.9 & 25.6 & 18.1 & 27.6 \\
\hline $\begin{array}{l}\text { Presence of Women in Aviation } \\
\text { International }\end{array}$ & 6.0 & 9.6 & 16.4 & 18.6 & 48.5 \\
\hline $\begin{array}{l}\text { Presence of Similar Gender } \\
\text { Faculty }\end{array}$ & 5.9 & 13.2 & 24.5 & 21.2 & 32.1 \\
\hline $\begin{array}{l}\text { Presence of Similar Gender } \\
\text { Students }\end{array}$ & 5.6 & 11.5 & 20.5 & 20.9 & 38.7 \\
\hline $\begin{array}{l}\text { Presence of Students with } \\
\text { Similar Racial Composition }\end{array}$ & 4.9 & 10.7 & 19.6 & 19.6 & 42.5 \\
\hline Presences of Alpha Eta Rho & 4.8 & 8.9 & 19.2 & 19.6 & 45.8 \\
\hline $\begin{array}{l}\text { Presence of Faculty with } \\
\text { Similar Racial Composition }\end{array}$ & 4.7 & 10.4 & 17.8 & 22.1 & 42.5 \\
\hline $\begin{array}{l}\text { Handicap/Disability Support } \\
\text { Services }\end{array}$ & 4.0 & 7.6 & 11.2 & 15.0 & 59.1 \\
\hline
\end{tabular}

Note. The values may not equal $100 \%$ due to missing data.

Table 6. Summary of Percentages for Factors of Females Choice of Four-Year Post-Secondary Commercial Aviation Program in Rank Order of Very Influential ( $n=98)$

\begin{tabular}{|l|l|l|l|l|l|}
\hline Survey Item & $\begin{array}{c}\text { Very } \\
\text { Influential } \\
\mathbf{( \% )}\end{array}$ & $\begin{array}{c}\text { Influential } \\
\mathbf{( \% )}\end{array}$ & $\begin{array}{c}\text { Somewhat } \\
\text { Influential } \\
(\mathbf{\%})\end{array}$ & $\begin{array}{c}\text { Minimally } \\
\text { Influential } \\
(\mathbf{\%})\end{array}$ & $\begin{array}{c}\text { Not } \\
\text { Influential } \\
\mathbf{( \% )}\end{array}$ \\
\hline Always wanted to be a pilot & 57.2 & 20.8 & 10.4 & 2.0 & 9.3 \\
\hline Program Educational Quality & 48.9 & 34.6 & 10.2 & 3.0 & 3.0 \\
\hline Availability of Scholarships & 37.5 & 20.8 & 16.6 & 7.2 & 17.2 \\
\hline Institutional Quality & 37.5 & 37.5 & 13.5 & 4.1 & 7.2 \\
\hline University Reputation & 36.4 & 39.5 & 12.5 & 4.1 & 7.2 \\
\hline Location of Institution & 35.4 & 26.0 & 20.8 & 8.3 & 9.3 \\
\hline Tuition and Fees & 34.3 & 20.8 & 14.5 & 10.4 & 19.7 \\
\hline Potential money in filed & 33.6 & 4.0 & 14.7 & 42.1 & 7.3 \\
\hline Small Class Size & 32.6 & 30.6 & 19.3 & 7.1 & 10.2 \\
\hline Availability of Financial Aid & 30.5 & 24.2 & 13.6 & 8.4 & 23.1 \\
\hline Student/Faculty Ratio & 29.5 & 26.5 & 19.3 & 12.2 & 12.2 \\
\hline
\end{tabular}




\begin{tabular}{|c|c|c|c|c|c|}
\hline Table 6 (continued). & & & & & \\
\hline Survey Item & $\begin{array}{c}\text { Very } \\
\text { Influential } \\
(\%)\end{array}$ & $\begin{array}{c}\text { Influential } \\
\text { (\%) }\end{array}$ & $\begin{array}{c}\text { Somewhat } \\
\text { Influential } \\
\text { (\%) }\end{array}$ & $\begin{array}{c}\text { Minimally } \\
\text { Influential } \\
\text { (\%) }\end{array}$ & $\begin{array}{c}\text { Not } \\
\text { Influential } \\
(\%)\end{array}$ \\
\hline Program Characteristics & 29.4 & 47.3 & 14.7 & 3.1 & 5.2 \\
\hline $\begin{array}{l}\text { Interactions/Perceptions of } \\
\text { Aviation Community }\end{array}$ & 28.5 & 42.8 & 20.4 & 3.0 & 5.1 \\
\hline Conditions of Equipment & 27.8 & 42.2 & 18.5 & 4.1 & 7.2 \\
\hline On-Campus Visit & 27.3 & 32.6 & 10.5 & 10.5 & 18.9 \\
\hline Safety Concerns & 26.5 & 38.7 & 14.2 & 10.2 & 10.2 \\
\hline Distance from Home & 26.0 & 20.8 & 21.8 & 12.5 & 18.7 \\
\hline $\begin{array}{l}\text { Availability to Work while } \\
\text { Attending Classes }\end{array}$ & 25.0 & 15.6 & 22.9 & 10.4 & 26.0 \\
\hline Faculty Reputation & 24.2 & 32.6 & 17.8 & 11.5 & 13.6 \\
\hline Campus Appearance & 23.9 & 28.1 & 21.8 & 13.5 & 12.5 \\
\hline Faculty Commitment & 23.1 & 32.6 & 25.2 & 6.3 & 12.6 \\
\hline Influence of a Family Member & 22.9 & 17.7 & 20.8 & 13.5 & 25.0 \\
\hline $\begin{array}{l}\text { Interactions/Perceptions of } \\
\text { Faculty }\end{array}$ & 21.8 & 29.1 & 27.0 & 8.3 & 13.5 \\
\hline Admission Criteria & 19.7 & 37.5 & 23.9 & 11.4 & 7.2 \\
\hline $\begin{array}{l}\text { Number of Years Program has } \\
\text { Existed }\end{array}$ & 18.9 & 21.0 & 25.2 & 14.7 & 2.0 \\
\hline Program Philosophy & 18.5 & 37.1 & 25.7 & 10.3 & 8.2 \\
\hline Length of Program & 17.3 & 35.7 & 28.5 & 14.2 & 4.0 \\
\hline Presence of WIA & 17.3 & 21.4 & 21.4 & 15.3 & 24.4 \\
\hline Familiarity of Campus & 16.6 & 22.9 & 29.1 & 15.6 & 15.6 \\
\hline $\begin{array}{l}\text { Campus Support Facilities } \\
\text { (computer lab, library, etc.) }\end{array}$ & 16.6 & 18.7 & 28.1 & 17.7 & 18.7 \\
\hline Presence of Flight Team & 16.3 & 17.3 & 19.3 & 20.4 & 26.5 \\
\hline Availability of Classes & 15.3 & 40.8 & 25.5 & 11.2 & 7.1 \\
\hline $\begin{array}{l}\text { Interactions/Perceptions of } \\
\text { Current Students }\end{array}$ & 14.7 & 29.4 & 25.2 & 14.7 & 15.7 \\
\hline Course Requirements & 14.4 & 42.2 & 25.7 & 10.3 & 7.2 \\
\hline Availability of Internships & 14.2 & 30.9 & 25.7 & 13.4 & 15.4 \\
\hline $\begin{array}{l}\text { Interactions/Perceptions of } \\
\text { Alumni }\end{array}$ & 13.4 & 26.8 & 21.6 & 17.5 & 20.6 \\
\hline Brochures/Pamphlets & 12.5 & 23.9 & 26.0 & 17.7 & 19.7 \\
\hline Student Body Diversity & 12.5 & 18.7 & 23.9 & 22.9 & 21.8 \\
\hline Faculty Mentorship & 11.4 & 21.8 & 31.2 & 16.6 & 18.7 \\
\hline
\end{tabular}




\begin{tabular}{|l|l|l|l|l|l|}
\hline Table 6 (continued). & \multicolumn{1}{|c|}{$\begin{array}{l}\text { Very } \\
\text { Influential } \\
\mathbf{( \% )}\end{array}$} & $\begin{array}{c}\text { Influential } \\
\mathbf{( \% )}\end{array}$ & $\begin{array}{c}\text { Somewhat } \\
\text { Influential } \\
\mathbf{( \% )}\end{array}$ & $\begin{array}{c}\text { Minimally } \\
\text { Influential } \\
\mathbf{( \% )}\end{array}$ & $\begin{array}{c}\text { Not } \\
\text { Influential } \\
\mathbf{( \% )}\end{array}$ \\
\hline Presence of Alpha Eta Rho & 10.5 & 7.3 & 17.8 & 16.8 & 47.3 \\
\hline Influence of a Friend & 10.4 & 8.3 & 23.9 & 22.9 & 34.3 \\
\hline Core Requirements & 9.3 & 40.6 & 35.4 & 8.3 & 6.2 \\
\hline Faculty Research & 7.3 & 17.8 & 25.2 & 24.2 & 25.2 \\
\hline $\begin{array}{l}\text { Presence of Similar Gender } \\
\text { Faculty }\end{array}$ & 6.3 & 9.4 & 22.1 & 24.2 & 37.8 \\
\hline $\begin{array}{l}\text { Presence of Similar Age } \\
\text { Students }\end{array}$ & 6.2 & 15.6 & 31.2 & 15.6 & 31.2 \\
\hline $\begin{array}{l}\text { Handicap/Disability Support } \\
\text { Services }\end{array}$ & 4.2 & 5.3 & 15.9 & 12.7 & 61.7 \\
\hline $\begin{array}{l}\text { Presence Similar Gender } \\
\text { Students }\end{array}$ & 4.1 & 6.2 & 27.0 & 19.7 & 42.7 \\
\hline $\begin{array}{l}\text { Presence of Faculty with } \\
\text { Similar Racial Composition }\end{array}$ & 4.1 & 7.2 & 13.5 & 23.9 & 51.0 \\
\hline $\begin{array}{l}\text { Presence of Students with } \\
\text { Similar Racial Composition }\end{array}$ & 4.1 & 7.2 & 16.6 & 18.7 & 53.1 \\
\hline Parking Availability & 3.1 & 11.5 & 18.9 & 26.3 & 4.0 \\
\hline Nore The valles & & & & \\
\hline
\end{tabular}

Note. The values may not equal $100 \%$ due to missing data.

Table 7. Summary of Percentages for Factors of Minority's Choice of Four-Year Post-Secondary Commercial Aviation Program in Rank Order of Very Influential $(n=120)$

\begin{tabular}{|l|l|l|l|l|l|}
\hline Survey Item & $\begin{array}{c}\text { Very } \\
\text { Influential } \\
\mathbf{( \% )}\end{array}$ & $\begin{array}{c}\text { Influential } \\
\mathbf{( \% )}\end{array}$ & $\begin{array}{c}\text { Somewhat } \\
\text { Influential } \\
\mathbf{( \% )}\end{array}$ & $\begin{array}{c}\text { Minimally } \\
\text { Influential } \\
(\mathbf{\%})\end{array}$ & $\begin{array}{c}\text { Not } \\
\text { Influential } \\
(\%)\end{array}$ \\
\hline Always wanted to be a pilot & 57.2 & 20.5 & 16.2 & 0.0 & 9.4 \\
\hline Program Educational Quality & 52.1 & 35.2 & 9.2 & 1.6 & 2.5 \\
\hline Institutional Quality & 43.1 & 32.7 & 17.2 & 5.1 & 2.5 \\
\hline University Reputation & 43.1 & 34.4 & 12.0 & 8.6 & 1.7 \\
\hline Availability of Scholarships & 38.7 & 22.4 & 17.2 & $11 . .2$ & 10.3 \\
\hline Potential Money in & 38.4 & 33.3 & 16.2 & 7.6 & 4.2 \\
\hline The Field Tuition and Fees & 36.2 & 25.0 & 14.6 & 10.3 & 11.2 \\
\hline Availability of Financial & 35.0 & 27.3 & 19.6 & 8.5 & 9.4 \\
\hline Aid Condition of Equipment & 34.1 & 44.1 & 15.0 & 5.8 & 2.5 \\
\hline Safety Concerns & 33.6 & 37.8 & 19.3 & 5.8 & 3.3 \\
\hline $\begin{array}{l}\text { Able to work while attending } \\
\text { classes }\end{array}$ & 32.7 & 15.5 & 24.1 & 14.6 & 12.9 \\
\hline $\begin{array}{l}\text { Interactions/Perceptions of } \\
\text { Aviation Community }\end{array}$ & 31.0 & 41.1 & 19.3 & 4.2 & 4.2 \\
\hline
\end{tabular}




\begin{tabular}{|c|c|c|c|c|c|}
\hline Table 7 (continued). & & & & & \\
\hline Survey Item & $\begin{array}{c}\text { Very } \\
\text { Influential } \\
(\%)\end{array}$ & $\begin{array}{c}\text { Influential } \\
(\%)\end{array}$ & $\begin{array}{c}\text { Somewhat } \\
\text { Influential } \\
(\%)\end{array}$ & $\begin{array}{c}\text { Minimally } \\
\text { Influential } \\
(\%)\end{array}$ & $\begin{array}{c}\text { Not } \\
\text { Influential } \\
(\%)\end{array}$ \\
\hline Small Class Size & 29.0 & 25.6 & 19.6 & 11.1 & 5.1 \\
\hline Location of Institution & 27.8 & 31.3 & 2.0 & 10.4 & 10.4 \\
\hline Distance from Home & 26.4 & 20.5 & 23.9 & 11.9 & 17.0 \\
\hline Student/Faculty Ratio & 25.8 & 34.1 & 23.3 & 11.6 & 5.0 \\
\hline $\begin{array}{l}\text { Campus Support Facilities } \\
\text { (computer lab, library, etc.) }\end{array}$ & 23.9 & 29.0 & 24.7 & 11.9 & 10.2 \\
\hline Program Characteristics & 23.5 & 33.9 & 11.7 & 4.5 & 2.6 \\
\hline On-Campus Visit & 23.4 & 26.9 & 26.0 & 9.5 & 13.9 \\
\hline Presence of Flight Team & 23.3 & 24.1 & 21.0 & 15.8 & 15.0 \\
\hline Faculty Commitment & 23.2 & 37.0 & 23.3 & 9.4 & 6.8 \\
\hline Course Requirements & 22.6 & 36.9 & 26.0 & 6.7 & 7.5 \\
\hline $\begin{array}{l}\text { Number of Years Program has } \\
\text { existed }\end{array}$ & 22.4 & 29.3 & 25.8 & 11.2 & 11.2 \\
\hline $\begin{array}{l}\text { Interactions/Perceptions of } \\
\text { Faculty }\end{array}$ & 22.4 & 22.4 & 37.9 & 11.2 & 4.3 \\
\hline Availability of Internships & 20.1 & 27.7 & 31.9 & 12.6 & 7.5 \\
\hline Campus Appearance & 19.8 & 37.9 & 28.4 & 12.0 & 1.7 \\
\hline Admission Criteria & 19.6 & 45.2 & 18.8 & 7.6 & 8.5 \\
\hline Familiarity of Campus & 18.4 & 29.8 & 22.8 & 17.5 & 11.4 \\
\hline Core Requirements & 14.1 & 35.8 & 33.7 & 9.6 & 5.3 \\
\hline Student Body Diversity & 18.1 & 31.0 & 25.8 & 9.4 & 15.5 \\
\hline Influence of a Family Member & 17.9 & 19.6 & 25.6 & 10.2 & 26.4 \\
\hline $\begin{array}{l}\text { Interactions/Perceptions of } \\
\text { Alumni }\end{array}$ & 17.7 & 25.4 & 23.7 & 19.4 & 13.5 \\
\hline $\begin{array}{l}\text { Interactions/Perceptions of } \\
\text { Current Student }\end{array}$ & 17.2 & 27.5 & 25.8 & 15.5 & 13.7 \\
\hline Availability of Classes & 16.0 & 40.8 & 25.8 & 10.8 & 5.8 \\
\hline Program Philosophy & 15.1 & 36.4 & 20.7 & 7.8 & 5.0 \\
\hline Faculty Mentorship & 14.5 & 25.6 & 27.3 & 13.6 & 9.4 \\
\hline Faculty Research & 14.5 & 24.7 & 32.4 & 13.6 & 9.4 \\
\hline Length of Program & 14.1 & 37.5 & 33.3 & 12.5 & 2.5 \\
\hline $\begin{array}{l}\text { Presence of similar Gender } \\
\text { Faculty }\end{array}$ & 13.7 & 19.8 & 20.6 & 19.8 & 25.8 \\
\hline Influence of a Friend & 12.8 & 23.0 & 26.4 & 14.5 & 23.0 \\
\hline Brochures/Pamphlets & 12.3 & 33.6 & 27.4 & 15.9 & 10.6 \\
\hline $\begin{array}{l}\text { Presence of Student s with } \\
\text { Similar Gender }\end{array}$ & 11.1 & 14.5 & 34.7 & 18.8 & 30.7 \\
\hline $\begin{array}{l}\text { Presence of Faculty with } \\
\text { similar racial comp. }\end{array}$ & 10.3 & 18.9 & 18.1 & 20.6 & 31.8 \\
\hline
\end{tabular}




\begin{tabular}{|c|c|c|c|c|c|}
\hline Table 7 (continued). & & & & & \\
\hline Survey Item & $\begin{array}{c}\text { Very } \\
\text { Influential } \\
(\%)\end{array}$ & $\begin{array}{c}\text { Influential } \\
\text { (\%) }\end{array}$ & $\begin{array}{c}\text { Somewhat } \\
\text { Influential } \\
\text { (\%) }\end{array}$ & $\begin{array}{c}\text { Minimally } \\
\text { Influential } \\
(\%)\end{array}$ & $\begin{array}{c}\text { Not } \\
\text { Influential } \\
(\%)\end{array}$ \\
\hline $\begin{array}{l}\text { Presence of Students with } \\
\text { Similar Age }\end{array}$ & 9.4 & 25.6 & 24.7 & 16.2 & 23.9 \\
\hline $\begin{array}{l}\text { Presence of Students with } \\
\text { Similar Racial Composition }\end{array}$ & 9.4 & 20.5 & 23.9 & 17.0 & 29.0 \\
\hline $\begin{array}{l}\text { Handicap/Disability support } \\
\text { services }\end{array}$ & 8.5 & 13.6 & 19.6 & 19.6 & 38.4 \\
\hline Presence of WIA & 8.3 & 2.0 & 18.3 & 10.8 & 42.5 \\
\hline Parking Availability & 6.8 & 18.1 & 22.4 & 21.5 & 31.0 \\
\hline Presence of Alpha Eta Rho & 5.9 & 15.2 & 21.1 & 16.9 & 40.6 \\
\hline & & & & & \\
\hline & & & & & \\
\hline
\end{tabular}

Note. The values may not equal $100 \%$ due to missing data.

\section{DISCUSSION OF THE RESULTS}

Research question one asked what factors influenced students to enroll in collegiate aviation programs. The results suggested that aviation itself was a very influential factor that encouraged students who enrolled in four-year post-secondary aviation programs. Specifically, the most frequently selected very influential factor was that they always wanted to be a pilot. Consistent with the findings of Mangan (2001), American aviation students enroll in four-year aviation institutions to train for a career flying for major airlines. Handicap /disability support services was the most frequently selected factor marked not influential. Pilot training is physical and requires standards set forth by the FAA. Students not meeting those Federal standards are not likely to enroll in four-year post-secondary aviation program

Similarly, female and minority students selected that they always wanted to be a pilot most frequently as the factor that was very influential. Additional factors listed as very influential included: program educational, institutional educational quality, availability of scholarships, university reputation, tuition and fees, availability of financial and potential money in the field.

Female and minority responses vary for two of the ten most frequently selected factors for selection of a four-year post-secondary aviation program. Female students selected location of institution and small class size. On the contrary, minority students selected condition of equipment and safety concerns. Four-year postsecondary aviation programs can concentrate on these factors to attract more female and minority students to collegiate aviation.

In contrast, what was not expected in this study was the impact of the two write-in answers that were available to the participants. The two most frequently reported written-in answers that were marked as very influential were "The ROTC program" (15.1\%) and "Faith or Mission based aviation programs" (14.9\%). These findings were not substantiated in the review of literature. These two factors represented $25.0 \%$ of the written-in answers.

Research question two asked what program and institutional characteristics attract students to collegiate aviation programs. The ten most frequently selected program and institutional characteristics that attract students to collegiate aviation were program educational quality, university, condition of equipment institutional educational quality, location of institution, small class size, safety concerns, and program characteristics, student to faculty ratio, and distance from home. This information is especially helpful to collegiate aviation 
programs that recruit students to their institution (Hurd, 2000). Consistent with Hamrick and Hossler (1996), this study found that despite many research studies on student selection no one conclusion can be drawn on institutional characteristics due to the variety of factors that influence student choice.

However, this study noted that the most frequently selected factors that attract students to four-year post-secondary aviation programs were similar across all gender and racial lines. Specifically, female and minority students selected program educational quality most frequently, as very influential. Additionally, female and minority students selected institutional quality, university, location of institution, small class size, student/faculty ratio, interaction/perceptions of aviation community, and the condition of equipment as very influential program and institutional factors.

Differences were noted among female and minority students on the program and institutional factors that were recorded as very influential. Specifically, in rank order, female students selected program characteristics 12 of 50 compared with 14 of 50 by the minority participants. Similarly, female students selected the on-campus visit 15 of 50, in rank order of very influential program and institutional factors, while minority students ranked it 24 out of 50. In contrast, minority students choose safety concerns 10 out of 50 in rank order of very influential while female students ranked it 22 out of 50. Finally, distance from home was ranked 15 out of 50 for minority students and 16 out of 50 for female participants.

Research questions three and four asked if there is a difference in factors that attract male and female or minority students to enroll in collegiate aviation programs. While the most frequently selected factors that attract aviation students are similar across gender and race lines, there are a few differences. The importance of Women in Aviation International (WIA) was statistically different for both female and minority students when compared with the overall group responses. These findings are consistent with Luedtke's (1993) study. Specifically, Luedtke found that female aviation students were interested in networking, joining professional organizations, participating in conferences, acquiring higher education degrees and as many flight ratings as possible, becoming more aggressive, seeking leadership from women, and being a role model for other women. Luedtke's results are all consistent with the mission of WIA. This study and Luedtke's confirm that the presence of WIA is influential to female collegiate aviation students. Similarly, the present study is consistent with Brazziel and Brazziel (1997) that student organizations and mentorship of students attract female and minority students.

\section{CONCLUSIONS}

This study found that $62.6 \%$ of the participants enrolled in their respective aviation program because they "wanted to be a pilot". Four-year post-secondary aviation programs should seek to attract students at the high school level with information regarding an aviation career. This suggestion reaffirms how vital The FAA's Aviation Education Program (ACE) is. Four-year post- secondary aviation programs should team up with the FAA, and their ACE program; that has been credited with guiding high school students to four-year post-secondary aviation programs (McGerald et al., 1993).

Additionally, this study confirmed the body of research concerning the under representation of female and minority students in four-year post-secondary aviation programs (Parish \& Lea, 1991; Bowen, 1990). Similarly, the number of female and minority pilots at the airline level is minimal when compared with Caucasian males (NAS Report, 1998; FAA, 2000; WIAI, 2001). However, it should be noted that at the time of this study there was little research in the area of students in four-year post-secondary aviation programs

The identified factors may be used to improve student selection and enrollment in aviation programs at institutions of higher learning. These factors may be implemented across disciplines to increase the number of female and minority enrollment. Additionally, this study may be used by institutions that are interested in developing four-year aviation programs that successfully attract students.

There are several ways to expand this study to provide further information to collegiate aviation programs regarding the factors that 
attract students. First, this study could be completed with successful students of four-year post-secondary aviation programs. The factors could be weighted to yield more definitive answers. Secondly, as a result of the successful student factors study, institutional recruiters could administer the survey to prospective aviation students to see if they are a good match for their aviation program.

More research is needed on the interaction between race and gender to examine why there are different factors that influence student selection of a collegiate aviation program. Further research is also needed to look at retention and completion rates by race and gender of students enrolled in four-year postsecondary aviation programs.

More research is needed to determine what socioeconomic factors impact selection of fouryear post-secondary aviation programs. Further research to determine the type (private and public) of institutions with four-year postsecondary aviation programs would be beneficial. This could give insight concerning the student populations given the great cost of aviation training. Economic information combined with the identified factors may be used by four-year post-secondary institutions to improve student selection and enrollment in institutions of higher learning aviation programs. Additionally, these factors may be implemented across disciplines to increase female and minority enrollment. This study may be used by institutions that are interested in developing four-year aviation programs that successfully attract students.

Additional research is warranted on the effect of ROTC and faith-based institutions with selection of a four-year post-secondary aviation programs. This study noted $25 \%$ of the writtenin survey items concerned ROTC and faith based institutions.

In summary, further research is needed to examine in greater detail the factors that influence selection and completion of four-year post-secondary aviation programs. This information at the collegiate level can be helpful in determining and training the students enrolled in four-year post-secondary aviation programs. 


\section{REFERENCES}

Ancrum-Smalls, P., Hagan, A., Kalbach, D., Smith-Wagner, S., \& Shepard, K. F. (2000). Factors important in physical therapist applicants' choice of a physical therapist program. Journal of Physical Therapy Education, 14(2), 9-24.

Astin, A. W. (1975). Preventing students from dropping out. San Francisco: Josey-Bass, Inc.

Astin, A. W. (1977). Four critical years: Effects of college on beliefs, attitudes, and knowledge. San Francisco: Josey-Bass, Inc.

Bowen, B. D. (1990). A trend analysis of women who hold federal aviation administration certificates relationship to the representation of women in collegiate aviation faculty ranks. The Wichita State University.

Brazziel, W. F., \& Brazziel, M.E. (1997). Distinctives of high producers of minority science and engineering doctoral starts. Journal of Science Education and Technology, 6(2), 143-153.

Clark, J. M., (2002). Enrollment numbers for commercial aviation students at Delta State University, Fall 2002 semester.

Clark, J. M. (2004). Factors influencing student selection of a four-year post-secondary commercial aviation degree. The University of Mississippi.

The Federal Aviation Administration (2001). Flying after 911. [Electronic version]. Retrieved July 21,2003, from http://faa.org

Gall, M. D., Borg, W. R., \& Gall, J. P. (1996). Educational Research (6 $\left.6^{\text {th }}\right)$. White Plain, N.Y.: Longman.

Hammerick, F. A., \& Hossler, D. (1996). Diverse information-gathering methods in postsecondary decision-making process. The Review of Higher Education, 19(2), 179-198.

Hossler, D. (1999). Effective admission recruitment. New Directions for Higher Education (108), 15-30.

Hurd, H. (2000). Staying power: Colleges work to improve retention rates [Electronic version]Black Issues in Higher Education, 17(18), 42-47. Retrieved October 31, 2001, from the EBSCOhost database.

Integrated Postsecondary Data System (IPEDS) “Fall Enrollment” surveys, Retrieved August 30, 2003 from http://www.nces.ed.gov

Karp, M. R., McCurry, W. K., Turney, M. A., \& Harms, D. (1999). Aviation education for future airline pilots: An integrated model. Retrieved October 15, 2002 from http://www.iats.jccbi.gov/1999/finalproceedings/session5d4.htm

Luedtke, J. R. (1993). Maximizing participation of women in collegiate aviation education. NIRA Report 93-14. (Doctoral dissertation, Oklahoma State University, 1993). National Institute for Aviation research, 041,HE025682.

Lipton, L. (2000). Aviation programs fight enrollment turbulence. Community College Week, 13(10), 1318.

Mangan, K. S. (2001). Aviation centers take off as airlines face pilot shortfall. Chronicle of Higher Education, 46(20), 47-49.

Manski, C. F., \& Wise, D. A. (1983). College choice in America. Cambridge, MA: Harvard University Press. 
McGerald, J., Nidds, J. A., \& Turney, M. A. (1993). Aviation career education: An exciting option [Electronic version]. Clearing House 67 (2) 103-105. Retrieved July 17, 2003, from the EBSCO host database.

Moore, P. (1999). Not enough women in aviation programs. Tech Directions , 59, 1.

SPSS Base 10.0 Application Guide. Chicago, IL: SPSS, Inc.; 1999.

SPSS Version 11.0 for Windows. Chicago, IL: SPSS, Inc.; 2002.

Parish, B., \& Lea, L. (1991). Overcoming stereotypes: Women in aviation. Initiatives, 54(2), 23- 33.

Stonewater, B. B. (1999). Collaborative admissions and recruitment practices. New Directions for Higher Education, 106, 45-50.

Tinto,V. (1987). Leaving College. Chicago: the University of Chicago Press.

U.S. Department of Education. (1992). Taking flight: Education and training. Retrieved October 2, 2002 from http://www.ed.gov/offices/OUS/PES/higher/civilai2.html

Women in Aviation International (2001). The Facts 2000: Women in U.S. Aviation. Retrieved October 1, 2001 from http://www.wia.org/resources/facts.htm. 